\title{
Kinetic study of methanolysis of African palm oil (Elaeis Guineensis) for biodiesel production
}

\section{Estudio cinético de la metanólisis del aceite de palma africana (Elaeis Guineensis) para la producción de biodiesel}

DOI: $10.46814 /$ lajdv3n5-039

Recebimento dos originais: 01/05/2021

Aceitação para publicação: 31/06/2021

\section{Alvarez Barrera}

Ma. del C. Chávez Parga., A. J. Castro Montoya

Facultad de Ingeniería Química, Universidad Michoacana de San Nicolás de Hidalgo. Morelia, Mich. Francisco J. Mújica S/N Edificio V1, Ciudad Universitaria Col. Felicitas del Río C.P. 58060 Morelia Michoacán, México.

\begin{abstract}
Biodiesel is nowadays one of the most important biofuel alternatives for diesel engines. The feasibility of its production on each country depends mainly on the raw material selected for this purpose and its availability. African palm has proved to be a good alternative for biodiesel's production in countries close to Ecuador due to the weather conditions help to have high oil yields by hectare. Kinetics of transesterification of this oil with methanol in a basic catalytic medium with sodium hydroxide was studied doing a statistical analysis to find the ratios of methanol and catalyst that allow the best yield of biofuel. The hydroxide ratio found was $0.6 \% \mathrm{w} / \mathrm{w}$ and the best methanol molar ratio was 5:1. Yields over $90 \%$ were obtained at low-medium temperatures in reaction times of 25 minutes. Kinetics of esterification of fatty acids with sodium hydroxide was also obtained as a complement of the study to show the impact of saponification in biodiesel's production.
\end{abstract}

Keywords: African palm, kinetics, transesterification, saponification, biodiesel.

\section{RESUMO}

O biodiesel é hoje em dia uma das mais importantes alternativas aos biocombustíveis para motores diesel. A viabilidade da sua produção em cada país depende principalmente da matéria-prima seleccionada para o efeito e da sua disponibilidade. A palma africana provou ser uma boa alternativa para a produção de biodiesel em países próximos do Equador, devido às condições climatéricas que ajudam a ter elevados rendimentos petrolíferos por hectare. A cinética de transesterificação deste óleo com metanol num meio catalítico básico com hidróxido de sódio foi estudada fazendo uma análise estatística para encontrar os rácios de metanol e catalisador que permitem o melhor rendimento do biocombustível. A razão de hidróxido encontrada foi de $0,6 \%$ p/p e a melhor razão molar do metanol foi de 5:1. Produções superiores a $90 \%$ foram obtidas a baixas temperaturas médias em tempos de reacção de 25 minutos. A cinética de esterificação de ácidos gordos com hidróxido de sódio foi também obtida como complemento do estudo para mostrar o impacto da saponificação na produção de biodiesel.

Palavras-chave: Palma africana, cinética, transesterificação, saponificação, biodiesel. 


\section{INTRODUCTION}

\subsection{FUNDAMENTALS ON BIODIESEL PRODUCTION}

Biodiesel is now one of the greater global importance transition energies. It is a synthetic liquid biofuel derived from natural fats such as vegetable oils or natural fats, new or used, by industrial processes of esterification and transesterification, and applied in the preparation of total or partial substitute of gasoil obtained from oil.

Refined vegetable oils or animal fats with low acidity are available to be used as fuel in combustion engines. However, the high viscosity of these raw materials decreases the atomization in the combustion chamber, and lead to have problems in the operation. To solve it some studies have been made to obtain fuel from vegetable oils, including hydrogenation. The way of obtaining simple alkyl esters from triglycerides by transesterification reactions with alcohols such as methanol or ethanol was early recognized [1].

Fatty esters are currently manufactured by the transesterification of triglycerides with light alcohols. Triglycerides are found mainly in vegetable oils or animal fats, commonly known as lipids. Transesterification reactions take place in presence of a catalytic medium, acidic or basic. The fatty ester is formed simultaneously with the formation of glycerol given by the rearrangement of the $\mathrm{OH}$ group. The complete reaction occurs in three stages that are controlled by chemical equilibrium, which are shown in figure 1:

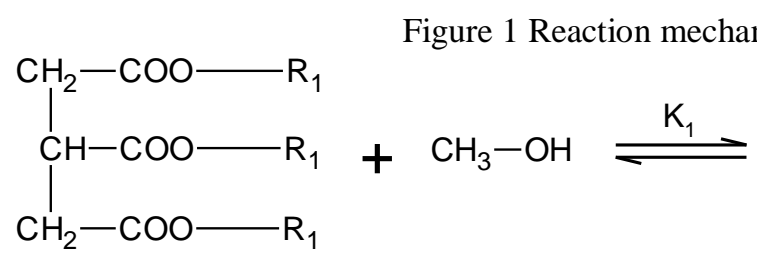

Triglyceride<smiles>[R]C(=O)CC(CO)(C([3H])=O)C(=O)O[18F]</smiles>

| Diglyceride<smiles>[R]OC(=O)CC(O)CO</smiles>

I Monoglyceride
$+\mathrm{CH}_{3}-\mathrm{OH} \stackrel{\mathrm{K}_{3}}{\rightleftharpoons}$

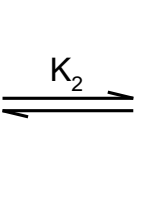<smiles>[R]C(=O)OC(=O)CC(O)CO</smiles>

Diglyceride<smiles>[R]C(=O)OCC(CC(=O)OC)C(CC(=O)OC)C(=O)OC</smiles>

Monoglyceride<smiles>OCC(O)CO</smiles><smiles>[3H]C(=O)OC</smiles>

Glycerol

Methyl esters 
From the moment the reaction is not fast at low temperatures it is required the use of catalyst. In fact, they make the difference between technologies. The catalyst can be acid or basic; can similarly be homogeneous or heterogeneous. The basic catalysts are preferred because they are faster. Homogeneous catalysis shows high activity but requires expensive post-processing stages. Either way, the solid catalyst-based technology and continuous operation are preferred [2].

The choice of the raw material used for the biodiesel production in the actually commercial plants depends mainly on geographic location, dominating the rapeseed oil in the EU, soybean oil in the US and Latin American, and palm oil in Asia. The use of virgin, edible oils for fuel production is controversial, and with the increasing prices, there is a growing interest in alternative feedstocks. This includes high-yielding, non-edible tropical crops such as Jatropha curcas. On a longer term, oil from marine microalgae has been proposed. Algae have oil productivities (L/ha/year) that far exceed that of any land-based crops, which is indisputably needed if we imagine biofuels to fully meet our global demand for transport fuels [3].

A selected group of alcohols and esters have been investigated for biodiesel synthesis in the literature [4]. Some examples of these special compounds are the alcohols with small alkyl chains as methanol, ethanol, 1- and 2-propanol, and butanol isomers [5, 6]. Nowadays, the name of commercial biodiesel is FAME (Fatty Acid Methyl Esters), formed by oil's transesterification with methanol, due to this compound reacts successfully in alkaline conditions and, in some regions, it is the cheapest alcohol. With increasing oil/gas prices and increasing production of bioethanol, the price structure could, however, change in the future. Part of the added cost of a heavier alcohol is also compensated by the increased mass (and volumetric) gain of biodiesel. With ethanol vs. methanol, the increased weight is that of one methylene group, corresponding to approx. 5\% of the biodiesel weight. However, alcohols with larger chains are reported to produce biodiesel with superior low temperature and crystallization properties $[7,8]$.

\subsection{BIODIESEL PRODUCTION PROCESSES}

\subsubsection{Batch processes}

First biodiesel production processes were essentially batch. In these the oil is fed to a stirred tank reactor in the presence of a large amount of methanol and a basic catalyst as sodium or potassium hydroxide [9] and the transesterification reaction is considered complete when the conversion exceeds $98.5 \%$, or when the mixture composition has the required quality specifications for biodiesel (EN14214, ASTM D6751). The non-reacting alcohol is recovered for the next batch and the glycerol and esters of the remaining mixture are separated by mechanical and chemical processes as decanting (that can be helped by water's addition to cause a separation phase [10]) or centrifugation. 
Batch processes have great flexibility with respect to composition of the feed but its economic indicators are low due to the productivity of equipment and its high operating costs.

\subsubsection{Continuous catalytic processes}

These are, actually, the most used processes for biodiesel production due to they are capable of processing a feed with a lot of free fatty acids, and unrefined vegetable oils. For this reason it becomes necessary a first reactor where the esterification of free fatty acids is carried out [11], preferably in a reactive distillation unit with solid catalyst [12].

\subsubsection{Supercritical processes}

Esterification in supercritical conditions has been studied initially as a way to solve the miscibility problems of the oils in methanol that presents kinetics under normal conditions. Either way, the pressure and temperature conditions are severe and require special equipment [13]. A recent research shows that actual performance may be reduced by thermal degradation of biodiesel. For this reason, increasing the temperature and pressure of the reaction is highly desirable [14].

\subsubsection{Enzymatic processes}

Transesterification reactions can be catalyzed by enzymes. The most currently used is the lipase due to its advantages and low temperature $[15,16]$. With a great pretreatment the reaction takes place at normal pressure and temperatures between 50 and 55 Celsius with low power consumption [17]. Methanolysis performance depends on several factors such as temperature, $\mathrm{pH}$, type of microorganism that produces the enzyme, the use of co-solvents, etc. Anyway, the low yields of methyl esters and long reaction time makes enzymatic processes are not competitive at present for the purposed raw material [18].

\subsection{ECONOMY OF THE BIODIESEL PRODUCTION PROCESS}

Graboski and McCormick [19] summarized a model for the production of 37.8 million liters (10 million gal) of biodiesel annually, concluding that the joint cost of feedstock and of its conversion to biodiesel would be US\$0.57/1 (\$2.15/gal). A high pressure transesterification process for the production of fatty acid esters from vegetable oils has been described in general terms, although without an economic analysis. Zhang et al. [20] presented a process design and technological assessment of biodiesel production from both virgin vegetable oil and waste cooking oil at near ambient pressures, but the report did not include an economic analysis of process costs. 


\subsection{KINETICS ON BIODIESEL PRODUCTION PROCESSES}

Kinetics of transesterification reaction has been studied for different raw materials using complex and very expensive techniques of gas chromatography to follow the disappearance of triglycerides and each one of their steps to the formation of FAME's [21] in a basic catalytic way. Formation of FAME's versus time has been reported for African palm oil using potassium hydroxide [22]. However the use of alkaline catalyst during reaction has the disadvantage of soaps formation on which kinetics represents a big impact factor for the process.

\section{MATERIALS AND METHODS}

Refined palm oil was obtained from Team Foods S.A. (México), certified methanol at $99.8 \%$ pure and sodium hydroxide pure grade were obtained from Merk (México). Experiments were carried out in different flasks of $250 \mathrm{~cm}^{3}$ maintaining constant temperature of 30 degrees and magnetic stirring of $900 \mathrm{rpm}$. Quantities of methanol, sodium hydroxide and palm oil were weighed in an analytical balance. The catalyst was dissolved in methanol and then the solution was added to the flask. After 30 minutes of reaction the stirring was stopped and light phase was separated from heavy phase. Excess of methanol and water were removed by heating in a furnace at $110{ }^{\circ} \mathrm{C}$ to get a constant weight. Soaps were removed from light phase using washing silica (Trisil $\left.{ }^{\circledR}\right)$ and the total weight of the formed fatty acid methyl esters was measured to calculate the reaction yield. This procedure was made for different molar ratios of methanol and catalyst by duplicate to know the impact of them in the reaction. Statistical analysis was made taking into account a significance level of $99 \%$.

When the best conditions of alcohol and catalyst were obtained, kinetics was studied in a different way at 40 and 50 degrees. After the addition of the prepared methoxide to the flask, the reaction was stopped at various times by neutralization of sodium hydroxide with an aqueous solution of hydrochloric acid 10\% w/w and separated into two phases. Both phases were weight and placed in a furnace at $80{ }^{\circ} \mathrm{C}$ to separate the remaining methanol. When constant weight was reached the weight of separated methanol was registered. Then, both phases were placed in a furnace at $110{ }^{\circ} \mathrm{C}$ to separate all water as made with methanol. Total water and separated salt weight were registered. By stoichiometric balance, the water formed during the acid neutralization was rested to the total water added to the experimental process to know the water quantity formed by the saponification reaction. Then remaining hydroxide weight was obtained by stoichiometric balance of the formed salt and registered. Glycerol and FAME's were weight and recorded. Non reactant fatty acids were separated by decanting. Each one of the recorded weights was divided by the total volume occupied by the mixture to know its concentration. 
After the study of kinetics and raw materials impact, biodiesel quality was obtained by the AOCS techniques. Iodine value, peroxide index, present soaps in ppm, density, viscosity, water content, acidity and oxidation stability were measured and compared with the norm ASTMD6751 to ensure a quality product.

\section{RESULTS}

Using gas chromatography the composition of fatty acids in the extracted palm oil was known (Table 1). In the first study, the catalyst to oil ratio was varied using a minimum alcohol to oil molar ratio of 5:1 (Table 2) and an analysis of variance was made to know the impact of the catalyst in the reaction at 30 degrees (Table3) with the next hypothesis.

$\mathrm{H}_{0}: \mu_{0}=\mu_{0.4}=\mu_{0.5}=\mu_{0.6}=\mu_{0.7}=\mu_{0.8}=\mu_{0.9}=\mu_{1}$

$\mathrm{H}_{1}$ : At less one $\mu$ is different.

Where the $\square$ subscripts are the used w/w catalyst to oil ratios.

Results obtained were:

Table 1 Composition of fatty acids contained in the extracted palm oil.

\begin{tabular}{|c|c|}
\hline Fatty acid & Compositión \% \\
\hline Lauric & 0.44 \\
\hline Myristic & 2.33 \\
\hline Palmitic & 41.53 \\
\hline Stearic & 4.74 \\
\hline Oleic & 38.22 \\
\hline Linoleic & 12.59 \\
\hline Linolenic & 0.15 \\
\hline
\end{tabular}

Table 2. Yields obtained on palm oil transesterification reaction at different catalyst ratios.

\begin{tabular}{|c|c|c|c|c|c|c|c|}
\hline \multicolumn{8}{|c|}{$\mathrm{NaOH}$ to oil used ratio \% w/w } \\
\hline $\mathbf{0}$ & $\mathbf{0 . 4 0}$ & $\mathbf{0 . 5 0}$ & $\mathbf{0 . 6 0}$ & $\mathbf{0 . 7 0}$ & $\mathbf{0 . 8 0}$ & $\mathbf{0 . 9 0}$ & $\mathbf{1 . 0 0}$ \\
\hline \multirow{2}{*}{$\begin{array}{c}\text { There's no } \\
\text { reaction }\end{array}$} & 62.30 & 72.40 & 87.45 & 92.10 & 83.05 & 75.57 & 65.52 \\
\cline { 2 - 9 }$y$ & 67.50 & 70.80 & 86.38 & 90.60 & 80.48 & 76.12 & 64.70 \\
\hline
\end{tabular}

Table 3 Analysis of variance for the impact of catalyst ratio on biodiesel production from palm oil.

\begin{tabular}{|c|c|c|c|c|}
\hline Source & Sum of squares & $\begin{array}{c}\text { Degrees of } \\
\text { freedom }\end{array}$ & Mean square & F test \\
\hline Catalyst & 1274.60 & 6 & 212.43 & 41.95 \\
\hline Error & 35.44 & 7 & 5.06 & \\
\hline Total & 1310.05 & 13 & & \\
\hline
\end{tabular}

$\mathrm{F}_{0.01,6,13}=4.62$ 
Then, there's a significant difference among the used treatments. To know where the difference is, it was necessary to do a contrast test between treatments with 0.6 and 0.7 with the others and one more only between 0.6 and 0.7 (Table4).

Table 4 Analysis of variance for contrast test of studied ratios of catalyst on African palm oil's transesterification.

\begin{tabular}{|c|c|c|c|c|}
\hline Source & Sum of squares & $\begin{array}{c}\text { Degrees of } \\
\text { freedom }\end{array}$ & Mean square & F test \\
\hline $0.6 \& 0.7$ vs others & 853.97 & 1 & 853.97 & 168.64 \\
\hline 0.6 vs 0.7 & 19.66 & 1 & 19.66 & 3.88 \\
\hline Error & 35.44 & 7 & 5.06 & \\
\hline Total & 19.66 & & & \\
\hline
\end{tabular}

$\mathrm{F}_{0.01,1,7}=12.25$

Therefore the main impact is located in the 0.6 and 0.7 treatments. Only the 0.6 value was used to make an impact study of methanol to oil molar ratio at the same conditions of temperature and reaction time (Table5) because of FAME's obtained from 0.7 value exceeded viscosity value of the norm ASTM D6751.

Table 5 Yields obtained of African palm oil's transesterification with different methanol molar ratios.

\begin{tabular}{|c|c|c|c|c|}
\hline \multicolumn{5}{|c|}{ Used methanol's to oil molar ratio } \\
\hline $\mathbf{5}$ & $\mathbf{6}$ & $\mathbf{7}$ & $\mathbf{8}$ & $\mathbf{1 5}$ \\
\hline 87.45 & 84.00 & 76.90 & 65.80 & 54.65 \\
\hline 86.38 & 83.50 & 75.40 & 67.20 & 52.20 \\
\hline
\end{tabular}

Analyses of variance for methanol ratio and contrast test of it are shown in tables 6 and 7 , respectively.

Table 6 Analysis of variance for the study of methanol ratio on biodiesel production from African palm oil with $0.6 \%$ catalyst.

\begin{tabular}{|c|c|c|c|c|}
\hline Source & Sum of squares & DF & Mean square & F test \\
\hline Methanol & 1487.87 & 4 & 371.96 & 320.93 \\
\hline Error & 5.79 & 5 & 1.15 & \\
\hline Total & 1493.67 & 9 & & \\
\hline
\end{tabular}

$\mathrm{F}_{0.01,4,9}=6.42$

Table 7 Contrast test for methanol's impact on the studied reaction.

\begin{tabular}{|c|c|c|c|c|}
\hline Source & Sum of squares & DF & Mean square & F test \\
\hline $5 \& 6$ vs $7,8 \& 15$ & 957.52 & 1 & 957.52 & 826.16 \\
\hline 5 vs 6 & 10.01 & 1 & 10.01 & 8.64 \\
\hline Error & 5.79 & 5 & 1.15 & \\
\hline
\end{tabular}

$\mathrm{F}_{0.01,1,5}=16.26$

Then, it is proved that at lower methanol ratios biodiesel yield increase. After this, kinetics of transesterification was studied at 40 and $50{ }^{\circ} \mathrm{C}$ obtaining values shown in tables 8 and 9 respectively. 
Table 8 Concentrations calculated from transesterification of African palm oil at different times and temperature of $40{ }^{\circ} \mathrm{C}$.

\begin{tabular}{|c|c|c|c|c|c|}
\hline \multirow[b]{2}{*}{ Concentration in g/ l } & \multicolumn{5}{|c|}{ Time in minutes } \\
\hline & $\mathbf{0}$ & 3 & 6 & 9 & 12 \\
\hline Non reactant fatty acids & 666.66 & 647.06 & 265.33 & 120.66 & 108.66 \\
\hline Methanol & 126.00 & 101.06 & 28.00 & 15.46 & 8.93 \\
\hline Glycerol & 0 & 9.06 & 37.20 & 47.33 & 53.60 \\
\hline Biodiesel & 0 & 39.73 & 290.80 & 439.20 & 455.60 \\
\hline Sodium hydroxide & 4.00 & 3.73 & 3.33 & 3.26 & 3.20 \\
\hline Soaps & 0 & 1.73 & 100.53 & 114.53 & 118.66 \\
\hline Water & 0 & 0.40 & 5.20 & 6.93 & 8.93 \\
\hline & 15 & 18 & 21 & 24 & 27 \\
\hline Non reactant fatty acids & 20.26 & 15.33 & 10.66 & 8.00 & 7.33 \\
\hline Methanol & 13.86 & 9.60 & 7.06 & 6.13 & 5.06 \\
\hline Glycerol & 60.26 & 61.06 & 62.40 & 62.66 & 62.06 \\
\hline Biodiesel & 508.66 & 561.33 & 564.00 & 565.46 & 567.33 \\
\hline Sodium hydroxide & 2.80 & 2.40 & 2.00 & 2.00 & 1.73 \\
\hline Soaps & 126.93 & 140.00 & 142.40 & 142.66 & 153.33 \\
\hline Water & 10.26 & 11.86 & 13.73 & 20.40 & 20.66 \\
\hline
\end{tabular}

Table 9 Concentrations obtained from transesterification of African palm oil at different times and temperature of $50^{\circ} \mathrm{C}$.

\begin{tabular}{|c|c|c|c|c|c|}
\hline \multirow[b]{2}{*}{ Concentration in g/ l } & \multicolumn{5}{|c|}{ Time in minutes } \\
\hline & 0 & 1.50 & 3 & 4.50 & 6 \\
\hline Non reactant fatty acids & 666.66 & 520.13 & 225.33 & 164.66 & 162.66 \\
\hline Methanol & 126.00 & 50.00 & 48.80 & 40.66 & 39.06 \\
\hline Glycerol & 0 & 28.26 & 33.60 & 37.86 & 40.53 \\
\hline Biodiesel & 0 & 158.13 & 316.53 & 344.53 & 375.33 \\
\hline Sodium hydroxide & 4.00 & 3.86 & 3.46 & 3.46 & 3.46 \\
\hline Soaps & 0 & 10.66 & 102.40 & 110.00 & 111.20 \\
\hline Water & 0 & 2.66 & 4.40 & 6.13 & 8.00 \\
\hline & 7.50 & 9.00 & 10.50 & 12.00 & 14.00 \\
\hline Non reactant fatty acids & 89.06 & 53.60 & 33.33 & 12.00 & 0 \\
\hline Methanol & 21.46 & 16.46 & 11.33 & 8.26 & 3.20 \\
\hline Glycerol & 45.86 & 48.26 & 54.80 & 59.60 & 60.66 \\
\hline Biodiesel & 440.53 & 470.00 & 507.33 & 541.33 & 571.06 \\
\hline Sodium hydroxide & 3.33 & 3.33 & 3.20 & 3.20 & 3.20 \\
\hline Soaps & 152.26 & 156.26 & 156.26 & 156.26 & 156.26 \\
\hline Water & 14.40 & 14.80 & 17.46 & 17.46 & 17.46 \\
\hline
\end{tabular}

Equation that describes disappearance of reactant fatty acids is:

$$
\frac{-d C_{a}}{d t}=K_{1} C_{a} C_{b}+K_{3} C_{a} C_{e}-K_{2} C_{c} C_{d}-K_{4} C_{f} C_{g}
$$


Where:

$\mathrm{Ca}=$ non-reactant fatty acids concentration

$\mathrm{Cb}=$ Methanol's concentration

$\mathrm{Cc}=$ Formed glycerol's concentration

$\mathrm{Cd}=$ FAME's concentration

$\mathrm{Ce}=$ Catalyst's concentration

$\mathrm{Cf}=$ Soap's concentration

$\mathrm{Cg}=$ Water's concentration

$\mathrm{K}_{1}=$ Kinetic constant of FAME's formation

$\mathrm{K}_{2}=$ Reverse kinetic constant of FAME's formation

$\mathrm{K}_{3}=$ Kinetic constant of soap's formation

$\mathrm{K}_{4}=$ Reverse kinetic constant of soap's formation

Solving this equation with the data obtained from experimental phase with differential method, the values of the last constants in $1 / \mathrm{h}$ are shown in table 10 :

Table 10 Kinetic constants of the analyzed system for two different temperatures in African palm oil's transesterification.

\begin{tabular}{|c|c|c|c|c|}
\hline Temperature & $\mathbf{K}_{\mathbf{1}}$ & $\mathbf{K}_{\mathbf{2}}$ & $\mathbf{K}_{\mathbf{3}}$ & $\mathbf{K}_{\mathbf{4}}$ \\
\hline $40{ }^{\circ} \mathrm{C}$ & 0.411 & 1.2805 & 34.7362 & 3.0386 \\
\hline $50{ }^{\circ} \mathrm{C}$ & 6.984 & 13.206 & 1084.266 & 18.79242 \\
\hline
\end{tabular}

Using lasts values, activation energies and preexponential factors for each one of the constants were calculated according to equations 2 and 3 to obtain the values shown in table 11:

$$
\begin{gathered}
E_{a}=\frac{R * T_{1} * T_{2}}{\left(T_{1}-T_{2}\right)}\left[\ln \frac{K_{1}}{K_{2}}\right] \\
A=\frac{K}{e^{\frac{-E a}{R T}}}
\end{gathered}
$$

Table 11 Activation energies and preexponential factors for founded kinetic constants in African palm oil's transesterification.

\begin{tabular}{|c|c|c|}
\hline Constant & Activation Energy [=] KJ/mol & Preexponential factor \\
\hline $\mathrm{K}_{1}$ & 238.330 & $6.5083 \mathrm{E} 35$ \\
\hline $\mathrm{K}_{2}$ & 196.317 & $1.9898 \mathrm{E} 29$ \\
\hline $\mathrm{K}_{3}$ & 289.4914 & $1.8815 \mathrm{E} 46$ \\
\hline $\mathrm{K}_{4}$ & 153.295 & $3.1443 \mathrm{E} 22$ \\
\hline
\end{tabular}

Finally, table 12 shows some of the main quality variables of the obtained product with a catalyst ratio of $0.6 \% \mathrm{w} / \mathrm{w}$ and a methanol molar ratio of 5 to ensure the product satisfies the main security and quality norms. 
Table 12. Quality specifications of the obtained palm oil's biodiesel

\begin{tabular}{|l|c|c|c|}
\hline & \multicolumn{3}{|c|}{ ASTM D6751 norm } \\
\hline Standard & $\begin{array}{c}\text { Palm oil's } \\
\text { FAME }\end{array}$ & Lower limit & Upper limit \\
\hline$\square \square$ at $15^{\circ} \mathrm{C}[=] \mathrm{Kg} / \mathrm{m}^{3}$ & 855.82 & $\ldots$. & $\ldots$. \\
\hline$\square \square$ at $40^{\circ} \mathrm{C}[=] \mathrm{mm}^{2} / \mathrm{s}$ & 4.7812 & $\mathbf{1 . 9}$ & $\mathbf{6}$ \\
\hline Oxidation stability $[=] \mathrm{h}$ & 20.01 & $\mathbf{3}$ & $\ldots .$. \\
\hline Water content $[=] \mathrm{mg} / \mathrm{Kg}$ & 237.7 & $\ldots$. & $\mathbf{5 0 0}$ \\
\hline Acidity $[=] \mathrm{mg} \mathrm{KOH} / \mathrm{g}$ & 0.15 & $\ldots$. & $\mathbf{0 . 5}$ \\
\hline Iodine value & 52.3 & $\ldots$. & $\ldots .$. \\
\hline Soaps content $[=] \mathrm{ppm}$ & 0 & $\ldots$. & $\mathbf{0}$ \\
\hline
\end{tabular}

\section{DISCUSSION}

Biodiesel production using African palm oil with basic homogenous catalysis has been frequently analyzed. However, some of the researches using this raw material seem to focus their attention in the obtained biodiesel yields, not in the main reaction kinetics, without explaining the used molar and weight ratios for methanol and catalyst, respectively [23]. Tables 2 to 7 show the importance of the statistical analysis of the catalyst and alcohol to oil ratios in the reaction to select one of the several conditions in this reaction. The obtained yield using a sodium hydroxide ratio of $0.6 \% \mathrm{w} / \mathrm{w}$ and methanol ratio of $5 \mathrm{had}$ an average value of $87 \%$ at $30{ }^{\circ} \mathrm{C}$ and 30 minutes of reaction. This value is higher to that obtained using acid heterogeneous catalyst $(79.6 \%$ and $83.3 \%$ with methanol ratios of 8 , reaction periods of $3 \mathrm{~h}$, catalyst ratios of 3 and 6 and temperatures between 127 and $190{ }^{\circ} \mathrm{C}$, respectively [24-25]) but lower to the reported yields with basic heterogeneous catalysis $(89.23 \%$ and $91.07 \%$ obtained with reaction periods between 2 and $9.72 \mathrm{~h}$, methanol molar ratios of 11.43 and 15, catalyst ratios between $3 \%$ and $6 \% \mathrm{w} / \mathrm{w}$ and temperatures of 60 and $65{ }^{\circ} \mathrm{C}$ [26-27]). A similar value of the present variable (87\%) was found using a strain of Aspergillus Niger after $72 \mathrm{~h}$ at $40{ }^{\circ} \mathrm{C}$ [28].

As seen, the used homogeneous catalyst offers acceptable yields with lower methanol and catalyst ratios, times of reaction and temperatures.

According to the tables 10 to 12, biodiesel's production from African palm oil is possible satisfying the quality norm ASTM D6751. The pre exponential factors and activation energies presented in the table 11 are higher than those found using subcritical conditions $\left(\mathrm{A}=1.62 * 10^{5}, \mathrm{Ea}=\right.$ 56.1 KJ / mol for temperatures of 150-200 ${ }^{0} \mathrm{C}$ and pressures of 140-190 atm [29]). However, these values were obtained only for the direct rate constant. It is, only for the step from oil and methanol to biodiesel and glycerol.

The value of the reverse kinetic constants for FAME's production in this work could be explained by water's formation during saponification of free fatty acids due to it can hydrolyze methyl esters returning them into fatty acids form. It's possible at low temperatures and finishes when all of 
free fatty acids have reacted. Nevertheless, although this reaction is present, yields of formed FAME's are high at low-medium times (less than 1 hour) with only one reaction step. The unwanted reaction (saponification) could be avoided by using a pre-treatment step in which free fatty acids are esterificated in an acid catalytic way but it requires a bigger reaction time and cares [30].

\section{CONCLUSIONS}

Biodiesel's production using refined African palm oil for FAME's formation is possible with a high yield (over 90\%) at low-medium temperatures in short reaction times (1/2 hour) using sodium hydroxide as catalyst and a short methanol molar ratio. Kinetics of FAME's production is affected by water's formation during free fatty acids esterification at low temperatures by the action of the basic catalyst used. This problem could be solved reducing the acidity of the extracted oil to a point close to 0 or adding an esterification phase in acidic medium before tranesterification. 


\section{REFERENCES}

[1] G. Knothe: The history of vegetable oil-based diesel fuels. In: “The Biodiesel Handbook”. Eds. G. Knothe, J. van Gerpen, J. Krahl, AOCS Press, Urbana, IL (USA) 2005, 4-16.

[2] Demirbass A; Biodiesel, a realistic fuel alternative for diesel engines. Ed. Springer, England, 2008, $111-139$.

[3] Y. Chisti: Biodiesel from microalgae. Biotechnol Adv. 2007, 25, 294-306.

[4] W. Du, Y. Xu, D. Liu, J. Zeng: Comparative study on lipase-catalyzed transformation of soybean oil for biodiesel production with different acyl acceptors. J Mol Catal B Enzym. 2004, 30, 125-129.

[5] L. Deng, X. Xu, G. Haraldsson, T. Tan, F. Wang: Enzymatic production of alkyl esters through alcoholysis: A critical evaluation of lipases and alcohols. J Am Oil Chem Soc. 2005, 82, 341-347.

[6] I. Lee, L. A. Johnson, E. G. Hammond: Use of branched-chain esters to reduce the crystallization temperature of biodiesel. JAm Oil Chem Soc. 1995, 72, 1155-1160.

[7] P. S. Wang, M. E. Tat, J. van Gerpen: The production of fatty acid isopropyl esters and their use as a diesel engine fuel. J am Oil Chem Soc. 2005, 82, 845-849.

[8] W.-H. Wu, T. A. Foglia, W. N. Marmer, R. O. Dunn, C. E. Goering, T. E. Briggs: Low-temperature properties and engine performance evaluation of ethyl and isopropyl esters of tallow and grease. JAm Oil Chem Soc. 1998, 75, 1173-1178.

[9] Lang X; Preparation and characterization of bio-diesels from various bio-oils. Bioresource Technology, 2001, 80, 53-62.

[10] Clements L., Hanna L.A, The effects of catalyst free fatty acids and water on transesterification of beef tallow. Trans ASAE, 1998, 41, 1261-1264.

[11] Sendzikiene E, Makareviciene V, Janulis P, Kytris S, Kinetics of free fatty acids esterification with methanol in the production of biodiesel fuel. European Journal of Lipid Science Technology, 2004, 106, 831-836.

[12] Fukuda H, Kondo A, Biodiesel fuel production by transesterification of oils. Journal of Bioscience and Bioengineering, 2001, 92, 405-416.

[13] Glisic S, Skala D, The problems in design and detailed analyses of energy consumption for biodiesel synthesis at supercritical conditions. Journal of Supercritical Fluids, 2009, 49, 293-301.

[14] Kiwjaroun C, Tubtimdee C, Piumsomboon P, LCA Studies Comparing Biodiesel Synthesized by Conventional and Supercritical Methanol Methods. Journal of Cleaner Production, 2009, 17, 143-153.

[15] Yuanyuan X, Wei D, Dehua L, Jing Z. A novel enzymatic route for biodiesel production from renewable oils in a solvent free medium. Biotechnology Letters, 2003, 25, 1239-1241.

[16] Noureddini H, Gao X, Philkana R. Immobilized Pseudomonas cepacia lipase for biodiesel fuel production from soybean oil. Bioresource Technology, 2005, 96, 769-777. 
[17] Feiyan X, Zhang X, Luo H, Tan T. A new method for preparing raw materials for biodiesel production. Process Biochemistry, 2006, 41, 1699-1702.

[18] Moreira A, Victor H. Biodiesel Synthesis by Enzymatic Transesterification of Palm Oil with Ethanol Using Lipases from Several Sources Immobilized on Silica-PVA. Energy \& Fuels, 2007, 21, 3689-3694.

[19] Graboski M.S., McCormick R.L. Combustion of fat and vegetable oil derived fuels in diesel engines. Prog. Energy Combust.Sci. 1998, 24, 125-164.

[20] Zhang, Y., Dube, M.A., McLean, D.D., Kates, M. Biodiesel production from waste cooking oil: 1 . Process design and techno-logical assessment. Bioresour. Technol., 2003, 89, 1-16.

[21] Berchmans H.J; Morishita K; Takarada T; Kinetic study of hydroxide-catalyzed methanolysis of Jatropha Curcas-waste food oil mixture for biodiesel production. Fuel, 2010 (Press), 89.

[22] Crabbe E., Nolasco H.C., Genta K., Kenji S., Ayaaki I. (2001), Biodiesel production from crude palm oil and evaluation of butanol extraction and fuel properties. Process Biochemistry 37.

[23] Recinos G., Rodríguez A., Hernández C., Yeomans J. Metodología para la fabricación de biodiesel a partir de aceite de palma africana (Elais Guineensis) y aceite de soya usado. Tierra Tropical. 2005. 1, 51-59.

[24] Fei K., Kansedo J., Teong K. Biodiesel Production from Palm Oil via Heterogeneous Transesterification: Optimization Study. Chem. Eng. Comm. 2010. 197, 1597-1611.

[25] Kansedo J., Lee K., Bhatia S. Biodiesel production from palm oil via heterogeneous Transesterification. Biomass and Bioenergy. 2009. 33(2), 271-276.

[26] Hameed B., Lai F., Chin H. Production of biodiesel from palm oil (Elaeis guineensis) using heterogeneous catalyst: An optimized process. Fuel Process Technol. 2009, 90(4), 606-610.

[27] Noiroj K., Intarapong P., Luengnaruemitchai A., Jai-in S. A comparative study of $\mathrm{KOH}=\mathrm{Al}_{2} \mathrm{O}$ and $\mathrm{KOH}=\mathrm{NaY}$ catalysts for biodiesel production via transesterification from palm oil. Renew. Energy. 2009, 34(4), 1145-1150.

[28] Xiao M., Sini M., Obbard J. A new isolated fungal used as whole-cell biocatalyst for biodiesel production from palm oil. GCB Bioenergy. 2010, 2, 45-51.

[29] Anusan P., Nakorn T., Tanogkiat K., Churat T., Sunanta W. Reaction Kinetics of Transesterification Between Palm Oil and Methanol under Subcritical Conditions. CS Canada EST. 2011, 2, 35-42.

[30] Siti Z., Chao L., Shaik R., Yi H. A two-step acid-catalyzed process for the production of biodiesel from rice bran oil. Bioresource Technology 1998, 96, 1889-1896. 